\title{
Size and Development of the Third Sector: An Insight Into Cross-Country Differences
}

UDK: $334.012 .46(045)$

\author{
Primož Pevcin \\ Univerza v Ljubljani, Fakulteta za upravo \\ primoz.pevcin@fu.uni-lj.si
}

\begin{abstract}
Non-profit or third sector is a very diverse sector and its socio-economic importance is rising in modern societies, although the way in which this sector is operating is changing dramatically, causing that dividing lines with for-profit and government sector are blurring. Nevertheless, quite substantial differences can be observed in the development and relative size of non-profit sector across countries, several factors potentially contributing to those differences. Consequently, the purpose of the paper is to theoretically and empirically investigate the effect of governmental interventionism, level of economic development and extent of societal heterogeneity on the variations in the size of the non-profit sector across countries, since theory predicts certain macro relations between those variables. Furthermore, the paper tries to address certain limitation and pitfalls of the development of non-profit sector in the future, predominantly related to increased pressures for commercialisation and performance orientation.
\end{abstract}

Key words: third sector, policy issues, cross-country variations, determinants

JEL: $L 31$

\section{Introduction}

As Hodgkinson and Weitzman (in Ott, 2001) point out, the so-called third or non-profit sector includes a diverse set of organisations, which basically serve public purposes, such as organisations in health, human services, arts, culture, education, 
Primož Pevcin

Size and Development of the Third Sector:

An Insight Into Cross-Country Differences

research, religious services, fund-raising and advocacy activities, etc. This sector is influenced by various factors, such as the state of national economy and public policies, changes in population and its preferences etc., but unique to this sector are certain sources of support, which are based on voluntary donations of time and other contributions. It should be noted that current economic crisis has more or less paralysed significant part of for-profit (business) sector, with the government policies in the majority countries being focused on the aftermath of such situation. Consequently, the relationship between the government and for-profit sector is increasingly changing from constitutionalism into paternalism, where economic activity is subjected to more intensive governmental subsidisation and regulation. However, economic slowdown actually positively affects the importance of the non-profit sector, as can we elaborate from the experience of previous economic crises. Namely, the non-profit sector is characterised by the fact that crisis situation increases demand for its products and services (such as charities, educational organizations, etc.), yet this sector is also characterised to be relatively less sensitive to economic trends, which refers to financial (and other) resources of organisations in the sector (NCVO, 2008).

Two main reasons for this lower sensitivity of non-profit sector are diversified resources and the in-build ability of non-profit organisations to mobilise resources, especially in crisis situations. Indeed, social networks, constituting a non-profit sector, allow extremely rapid and effective mobilisation of especially human resources, enabling the organisations within the sector to achieve certain objectives without necessity to establish state coercion or to provide economic incentives. In fact, the functioning of non-profit sector is based, according to Ott (2001), on the existence of so-called economies of grants, which include voluntary donation of time, money, etc. This enables the sector, contrary to state coercion or market economy, to operate in almost all areas of social life, often quite independently of the current political and economic conditions. Notwithstanding, substantial differences exist in the development and relative socio-economic importance of non-profit sector among countries, even among developed ones. In essence, demand as well as supply side hypotheses could be provided in relation to the development and size of the non-profit sector. Demand side hypotheses usually focus on the third sector role in providing goods and services that are not adequately provided by for-profit and government sector. In contrast, supply side hypotheses contemplate that size of the non-profit sector is related to the extent of resources available to the sector, which should, among others, depend also on the wealth of certain society. Indeed, previous research 
on the size of the non-profit sector, as for instance analysis presented by Grønbjerg and Paarlberg (2001) for selected counties in the United States, reveals that the size of the non-profit sector is most sensitive to opportunity structures created by community social and political conditions, meaning that supply side factors should be more important than demand side factors in determining the size of the non-profit sector. These differences in the size of the non-profit sector cause that different regime types of non-profit sector activities could be established in different countries. These regime types directly address the relationship between government and non-profit sector in providing certain public goods and services. Consequently, the main purpose of the paper is to investigate potential causes of cross-country differences in the extent of non-profit sector activities and empirically validate potential regime types of non-profit sector activities in selected countries. In essence, this paper in some way extends the research by Salamon and Sokolowski (2001) in a sense that it tries to group selected countries into different regime types of non-profit sector activities according to social origins theory. In addition, paper tries to relate the size of the non-profit sector to the level of economic development and ethno-cultural heterogeneity of selected countries, purpose being to gain insight into supply side and demand side perspectives of the determinants of the variations in the non-profit sector size across countries. In short, the purpose of the paper is to theoretically and empirically investigate the effect of governmental interventionism, level of economic development and extent of societal heterogeneity on the variations in the size of the non-profit sector across countries, since theory predicts certain macro relations between those variables. Furthermore, the paper addresses some potential pitfalls for the development of the non-profit sector in the future, especially the changes driven by commercialisation and performance orientation.

\section{Structure and development of the non-profit sector}

It should be noted that the non-profit sector is a very diverse sector, although much of its activities are concentrated in the fields of culture and recreation, education and research, health and social services (see figure 1). Actually, according to readings in Ott (2001), this sector emerged due to the four distinguished 
Primož Pevcin

Size and Development of the Third Sector:

An Insight Into Cross-Country Differences

forces, those forces being the existence of market and government failure in the provision of certain goods and services to citizens, the emergence of pluralism and individual freedom in modern societies as well as the increased pressures on solidarity among people. Basic characteristic of the non-profit organisations is that the main goal of their activities is not the recovery of investment costs and profit maximisation ${ }^{\mathbf{1}}$, but primarily the advancement of certain social (or public) goals.

Figure 1: Fields of non-profit sector activities and shares of their contribution to GDP, 7-country average for the period $1999-2004^{2}$

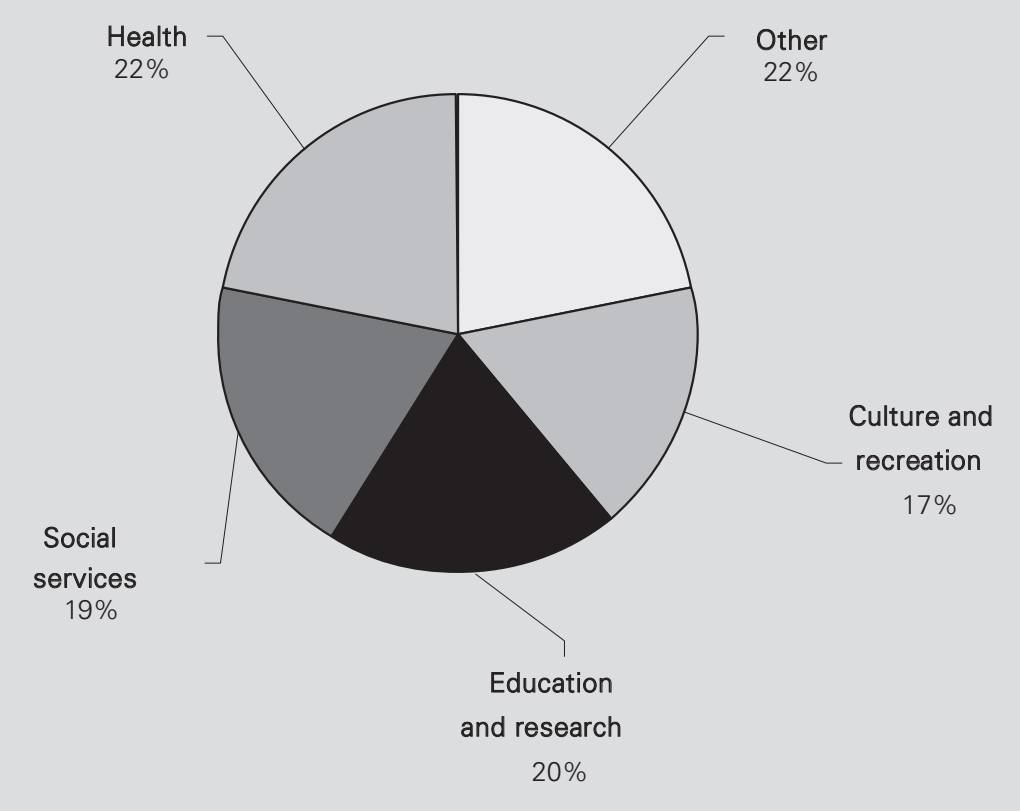

Source: Salamon et. al. (2007)

1 Although these contingent profits are desirable in order to be reinvested for development of existing and new organisational activities.

2 Data represent 7-country average for the period 1999-2004, analysed countries being Australia, Belgium, Canada, Czech Republic, France, Japan and New Zealand. For more information see Salamon et.al. (2007). 
Primož Pevcin

Size and Development of the Third Sector: An Insight Into Cross-Country Differences

The essence of the non-profit sector (also called the independent ${ }^{3}$ or third sector) is that it receives resources and revenues for its operation from many different sources. Actually, in the past the most important sources were voluntary donations by individuals and business sector. However, recently observed trends, which can be also elaborated from Figure 2, show, that user fees and other sources from commercial activities are increasingly replacing governmental funding, while grants have become, relatively speaking, quite negligible. This has occurred predominantly due to the fact that in recent years significant trends and pressures exist for larger commercialisation of the activities of non-profit organisations, which are caused predominantly by changes in the system and the amount of budgetary and grant financing.

Figure 2: Non-profit sector revenue sources, 26-country average for $1995^{4}$

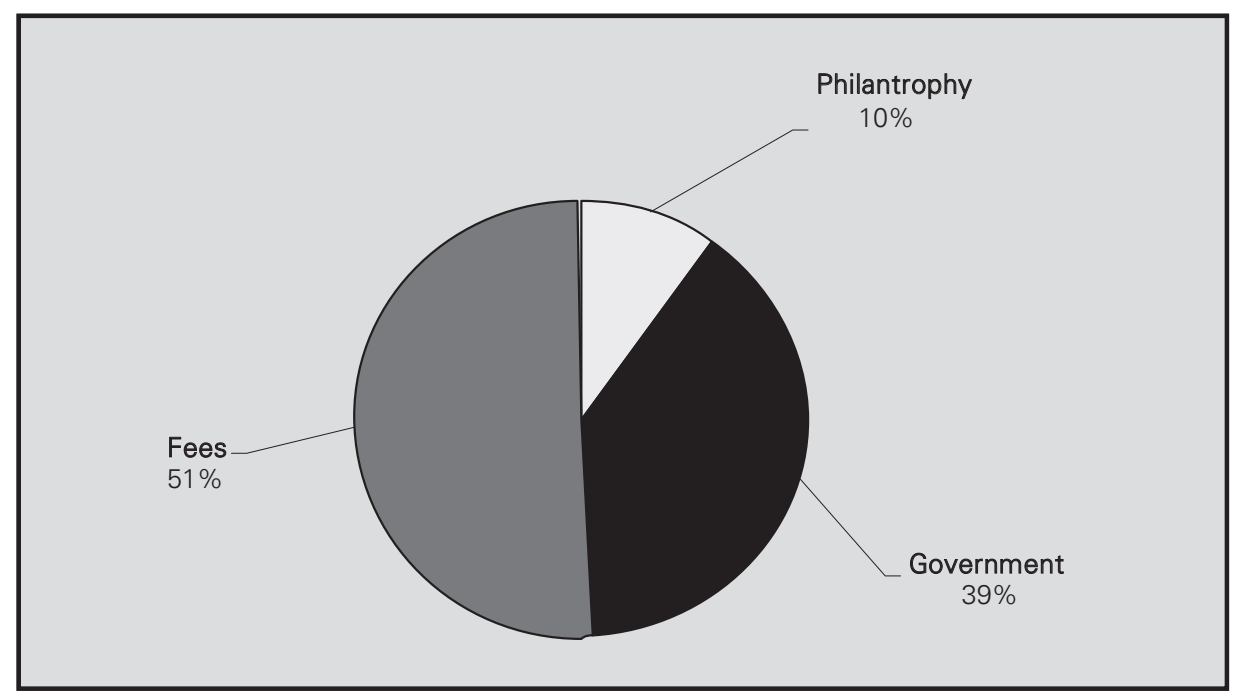

Source: The John Hopkins Comparative Nonprofit Sector Project (2004)

3 The use of term independent can be highly misleading, since it is highly difficult to be pragmatically independent when you are dependent on external resources as are the nonprofit organisations (Ott, 2001). Basically, the term independent describes the ability to carry out certain social goals and missions without being constrained by the need for economic efficiency or political support.

4 Data represent 26-country average for 1995. It should be noted that substantial regional differences exist in relative importance of each source of revenue. For instance, in analysed Western European countries government sources still represent the largest single source of revenue of non-profit organisations, whereas in analysed Latin American countries fees represent almost three quarters of all sources of non-profit organisations. For more detailed insight in data see The John Hopkins Comparative Nonprofit Sector Project (2004). 
Primož Pevcin

\section{Size and Development of the Third Sector:}

An Insight Into Cross-Country Differences

It should be acknowledged that the main cause for existence of the nonprofit sector is the provision of certain public goods and services, which is similar to government sector activities, yet it should be noted that, technically, non-profit sector is not part of the government (public) sector. Namely, the non-profit sector activities rely primarily on the ideas of individualism and pluralism, rather than on ideas of equality and justice that are prevailing in the government sector, which also represents the dividing line between these two sectors. This means that in practice the non-profit organizations try to avoid delivering universal and compulsory public goods and services, as does the government sector, but rather those public (or better collective) goods and services, which are determined by the willingness of individuals, businesses, governments, and other institutions in society to cooperate with non-profit organizations in order to realise their missions and goals. The existence of the non-profit sector is, in fact, the result of the development of democratic society and the capitalist economic system, where non-profit sector exists for the purpose of elimination or reduction of market and government failures in provision of certain goods and services or in meeting certain needs of citizens. ${ }^{5}$ Indeed, Weisbrod (1998) says that the relative importance of non-profit sector increases with the increasing heterogeneity of modern societies, which causes that the preferences and needs of citizens more and more differ, thereby decreasing demand for universal public goods and services but increasing demand for public goods and services with more individualistic and pluralistic characteristics. ${ }^{6}$

Furthermore, also the failures of for-profit sector increase the need for the existence of non-profit sector. These failures can be described as market or contract failures, which are predominantly caused by imperfections in market

5 Intuitively, it can be concluded that in crisis situation both market and government failures increase, indicating that the relative socio-economic importance of non-profit sector should increase.

6 In this context, particularly interesting should be the relationship between welfare state retrenchment and the role of the non-profit sector. Namely, the evidence exists for supporting the thesis that voters will find the redistribution policies, which can mainly be observed in government transfer spending, more appealing in socially more homogeneous societies (see e.g., Annett, 2000). Nevertheless, this should impose certain implicit restrictions on the further development of welfare state and its expansion, which is not connected to the prevailing fiscal limitations; it should be noted that increased social fractionalisation, which has characterised the majority of developed countries in recent years, obviously affects the political process and decreases preferences for any extensive formulation and implementation of certain social policies. Since this dynamic will obviously also predominate in the future, further limitations on welfare state development and expansion are to be expected. This means that the functions of welfare state should become increasingly the domain of non-profit organisations, as well as also in part the domain of the for-profit sector, predominantly through its so-called socially responsible activities. 
relationship as well as informational asymmetry, which causes that providers can exploit market position and the ignorance of buyers to maximise their interest (Grønbjerg in Ott, 2001). In this sense, because non-profit sector organisations have less incentives and possibilities to exploit buyers' ignorance, they are usually more trusted in providing certain goods and services, which are characterised by large market imperfections or the existence of important informational asymmetries (e.g., education, counselling etc.).

\section{Non-profit sector operations and pitfalls of contemporary policies in this area}

In recent years and decades significant trends and pressures exist for larger commercialisation of the activities of non-profit organisations, which are caused predominantly by changes in the system and the amount of budgetary and grant financing. This section investigates some significant changes facing the sector, special emphasis given on particularly vulnerable aspect of the financing of the non-profit sector. Namely, the main force that the non-profit organisations are facing recently is the emergence of ever-increasing demand for commercialisation of their activities, which can be observed, also form figure 2 where user fees have, on average, become the most important revenue source of non-profit organisations. ${ }^{7}$ This growing pattern has been described by Weisbrod (1998) with the fact that non-profit museums are opening retail shops, non-profit universities are engaging in research networks with private firms, non-profit hospitals are opening various health clubs etc. This commercialisation of the activities has been based on the ideology of the new public management, which heavily influenced governmental policy-making in recent decades, basically promoting the idea of increasing market orientation of governmental and

7 This assertion relates to non-profit organisations in general. It should be quite understandable that for some organisations, such as charities etc., this assertion does not hold. Similarly, Anheier (2000) reports that user fees and charges were in 1990 the most important source of revenues for third sector organisations in Hungary, Italy, Sweden, Japan, United Kingdom and United States, but not in France and Germany, although this share has, nevertheless, quite substantially increased till 1995 in those two countries. In particular, the commercialisation of third sector activities could be found particularly important in more liberal and corporatist regimes as described in section 4 . 
Primož Pevcin

\section{Size and Development of the Third Sector:}

An Insight Into Cross-Country Differences

non-profit organisations. ${ }^{\mathbf{8}}$ These requirements and policy issues have usually been expressed more indirectly, mainly with the changes in the extent of governmental funding, which required from non-profit organisations to be more market oriented, if those organizations even wanted to operate normally. Although the commercialisation of activities is actually in contradiction with the basic purpose of non-profit organisations, that is to be non-profit, it has now become a predominant form of operation for a substantial part of non-profit organisations in practice.

In general, the majority of non-profit organisations have been relatively successful when facing the need of increased commercialisation of their activities, yet this has generated some possible problems for them. One of the problems is related to the increased cooperation with the for-profit sector, which can often result in certain limitations imposed on the activities of nonprofit sector. This can seriously affect the autonomy of non-profit organisations, also possibly putting at risk the goals and values of their initial mission (Macedo and Pinho, 2006)..$^{\boldsymbol{9}} \mathrm{A}$ typical example is the cooperation of universities with business corporations, where certain limitations can be put on the dissemination of scientific findings, especially those that are not in line with the expectations, needs or strategy of corporation. Moreover, another problem of such arrangements is their instability, but we should not neglect the fact that universities are usually less cost-effective organisations in relation to other competing research organisations, a real danger being the "outsourcing " of research activities from universities (Ott, 2001).

Nonetheless, a substantial change has also occurred in the forms of governmental funding of non-profit organisations, which has become increasingly performance oriented. It should be acknowledged that the positive effects of performance oriented budgeting - for instance increased allocative, managerial or stabilising role of the budget ${ }^{10}$ - are usually addressed from the governmental point of view. However, certain traps exist for non-profit organisations when this concept of financing is introduced. First of all, performance oriented budgeting inevitably puts the focus on measurable efficiency of non-profit organisations, which, according to Euske (2003), forces non-profit organisations

8 It should be stressed that this ideology was, and in some instances still is, very influential in policy making, also in post-socialist countries.

9 This can potentially lead to so-called organisational isomorphism, where non-profit organisations can start to resemble their resource providers.

10 More on the issue of programme and performance oriented budgeting see Robinson (2007). 
to seek economies of scale. Notwithstanding, this can cause the loss of the responsiveness of the non-profit organisations to certain societal needs.

Second, experience of certain countries, which have implemented performance oriented financing in the classical non-profit areas of education and health, reveals relative inefficiency and limitations of using performance indicators as a foundation for the amount of governmental financial support. Namely, those indicators and criteria for funding are usually based on the amount of "production " of each institution, as for instance so-called taximeter model

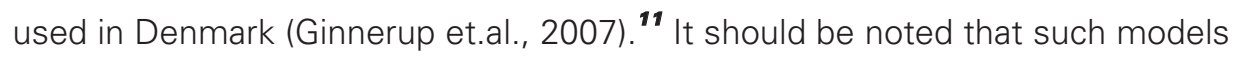
of financing can easily cause unintended effects on motivation of organisations receiving funds as they can lower the criteria in order that more students actually pass the exam or patients receive more medical treatments that are actually needed. ${ }^{12}$

\section{Socio-economic importance and cross-country differences in the size of the non-profit sector}

The non-profit sector currently represents important part of economical, political and social environment of almost all developed countries. It namely complements government and markets in the provision of important services, especially in health, education and social fields. ${ }^{13}$ However, relative socioeconomic importance of the non-profit sector substantially differs among countries. For instance, as it can be observed from table 1, the size of the non-profit sector, if measured with the share of its workforce in economically active

11 For instance, educational institution obtains funds for each student that passes the each year required exams; health institution obtains funds on the number of medical treatments that it actually performs etc.

12 This was the experience of Norway, where they have experienced large difficulties in implementing performance oriented budgeting in practice (Anderson et.al., 2006). Similarly, the experience of the United States reveals that performance budgeting does not have immediate and substantial effect on the improved efficiency and effectiveness of organisations, where specifically graduation rates are seen as very biased form of measure, as it tends to increase artificially after it is put up as performance measure (Shin and Milton, 2004).

13 Furthermore, the trend exists of rapid growth in both scale and scope of the non-profit sector due to rising heterogeneity of population, caused by larger human migrations and information flows. This trend can be observed in the vast majority of democratic countries around the world, also termed as "associational revolution" (more on this see Salamon, 1994). 
Primož Pevcin

Size and Development of the Third Sector:

An Insight Into Cross-Country Differences

population ${ }^{\mathbf{1 4}}$, is relatively low in former socialist countries. In contrast, the size of non-profit sector is relatively large in Western and Northern European countries as well as in Anglo-Saxon countries.

Table 1: Non-profit sector workforce ${ }^{15}$ as a percent of the economically active population in selected countries, 1995-2000

\begin{tabular}{|l|c|c|c|}
\hline Country & NPS workforce (\%) & Country & NPS workforce (\%) \\
\hline Australia & 6,3 & Japan & 4,2 \\
\hline Austria & 4,8 & Netherlands & 14,4 \\
\hline Belgium & 10,9 & Norway & 7,2 \\
\hline Czech Republic & 2,0 & Poland & 0,8 \\
\hline Finland & 5,3 & Romania & 0,8 \\
\hline France & 7,6 & Slovakia & 0,8 \\
\hline Germany & 5,9 & South Korea & 2,4 \\
\hline Hungary & 1,1 & Spain & 4,3 \\
\hline Ireland & 10,4 & Sweden & 7,1 \\
\hline Israel & 8,0 & United Kingdom & 8,5 \\
\hline Italy & 3,8 & United States & 9,8 \\
\hline
\end{tabular}

Source: The John Hopkins Comparative Nonprofit Sector Project (2004)

First of all, it should be stressed that the non-profit sector is relatively well developed in the United States, which is a direct consequence of certain historical circumstances related to the role of the government in society. Namely, significant sharing of control and accountability for the individuals to provide certain common needs of local communities was observed in the United States in the 19th century, which was a direct result of lack of governmental

14 Using this variable as a proxy for measuring the size of non-profit sector is quite reasonable, given the fact that the lack of internationally comparable data exists, which can be attributed, among others, to very large diversity of activities and organisational forms that non-profit organisations perform and exist in.

15 Data do not include religious organisations. 
Primož Pevcin

Size and Development of the Third Sector: An Insight Into Cross-Country Differences

coercion mechanism that would ensure those needs. In contrast, governments in Europe already had the ability at that time to ensure certain common needs of citizens and communities, which was the reason volunteering and philanthropy were less needed in European countries. These differences can be observed even in recent times, as volunteering and philanthropy are much more developed in the United States than in the majority of European countries. Given the fact that these two concepts represent a "backbone " of the non-profit sector, it is quite understandable that non-profit sector is more developed in the United States than in Europe. ${ }^{\mathbf{1 6}}$ In addition, it should also be stressed that the activities of non-profit organizations are usually hampered in totalitarian political regimes, as the tendency exists there for political system and government to dominate civil society. For instance, this experience can be observed in post-socialist countries, where the size of the non-profit sector is still smaller than in compared industrial countries, following the data in Table 1. ${ }^{\mathbf{1 7}}$

Notwithstanding, an important aspect on the discussion about non-profit sector is the question, how should we explain cross-country differences in the extent of non-profit activity, which can be observed from table 1. Basically, three different approaches can be taken for this purpose according to Salamon and Sokolowski (2001), these approaches being macro-structural approach, micro-structural approach and social origins theory. In general, authors argue that in particular micro-structural approach and social origins theory can be used as a solid backbone for explaining cross-country differences in non-profit activities, whereas macro-structural approach has relatively limited domain in forming solid explanations. In short, macro-structural approach contemplates that the greater governmental involvement in the production of (public) goods and services crowds out other providers of these goods and services, such as for instance non-profit organisations or various social solidarity networks, thereby also restricting the development of trust and philanthropy. In contrast, micro-structural approach envisages that the amount of non-profit activity is affected by the existence and the amount of social networks that encourage volunteering.

16 More on historical and social reasons for differences in the development of the non-profit sector between European countries and the United States see readings in Ott (2001). It should be noted, that this relationship could not be resumed for all European countries, since non-profit sector is, compared to the United States, relatively larger in the Netherlands, Belgium and Ireland (see table 1). This is due to the existence of some country-specific factors causing larger relative importance of the non-profit sector.

17 More on the development of non-profit sector in post-socialist countries see e.g. Brhlikova (2004), Svitkova (2004) or Giving in Europe (2009). 


\section{Primož Pevcin}

\section{Size and Development of the Third Sector:}

An Insight Into Cross-Country Differences

Finally, social origins theory argues that the size of non-profit sector is an outcome of power relations among social classes and key social institutions, describing those relations in four broad social regime types, that is statist, social-democratic, liberal and corporatist type. In general, statist and socialdemocratic social regimes are described by the fact that the importance of non-profit sector is relatively low, although in the latter regime due to vast existing social welfare and transfer spending of government; in the former regime predominantly due to limitations on social activities imposed from ruling elites in society. However, liberal and corporatist social regimes can be described by the fact that the importance of non-profit sector is relatively high, although in the former due to relatively low governmental interventionism in social welfare activities, which are left for non-profit sector to be carried out, whereas in the latter non-profit sector serves as traditional mechanism of extending governmental social welfare policies. The regime types can be represented in the following matrix.

Figure 3: Regime types of non-profit sector activity

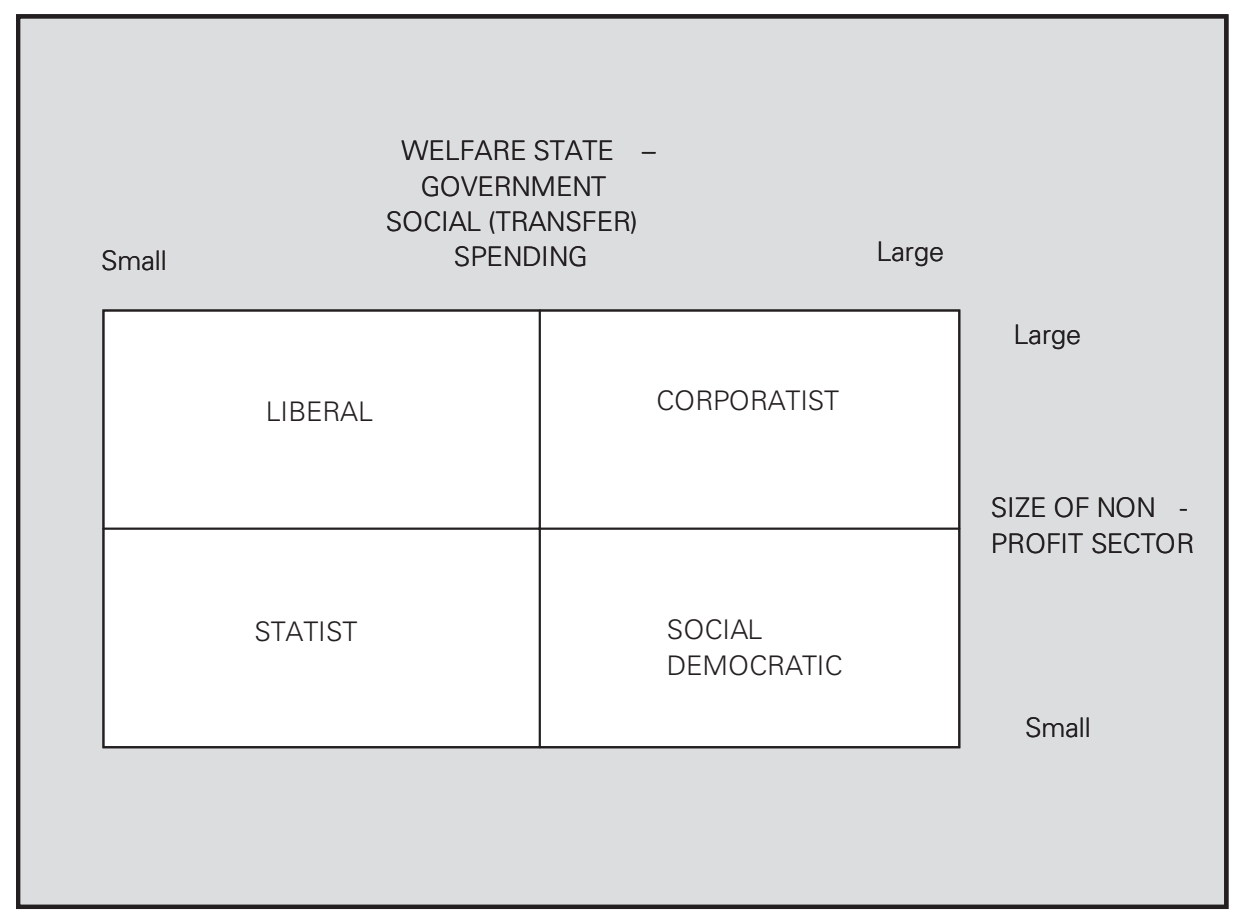

Source: based on Salamon and Sokolowski (2001) 
Consequently, given the fact that the measurement of social networks is relatively difficult on aggregate level, the empirical analysis and validation of social origins theory is presented in the next section. Furthermore, the relationships between the size of non-profit sector and the level of economic development as well as the social fractionalisation of population are also tested.

\section{Variations in the size of the non-profit sector - empirical analysis}

The purpose of the chapter is to empirically investigate the relationship between the size of the non-profit sector and the size of government spending, level of economic development, and ethno-cultural heterogeneity of society. The purpose of the empirical analysis is to gain insight into validity of social origins theory, as well as in supply and demand side factors that shape non-profit sector social importance and development across country. The empirical analysis is based on the sample of selected 22 countries with different social, political and economic traditions, for which internationally comparable data on the size of non-profit sector are available. ${ }^{\mathbf{1 8}}$ The presumption is that reasonable proxy for determining the size of non-profit sector is the share of non-profit sector workforce in economically active population and reasonable proxy for determining the extent of welfare state is the share of governmental transfer spending in GDP, which includes non-compensatory spending of government on welfare, social security, business subsidies, etc. The results of the analysis are presented in figure $4 .{ }^{19}$

\footnotetext{
18 It should be stressed that it is hard to obtain internationally comparable data for the size of the non-profit sector in different countries, potential reason being the diversity of the sector and variations in organisational forms within the sector. Therefore, the paper builds on the data gathered by The John Hopkins Comparative Nonprofit Sector Project (2004).

19 Both variables are standardised in order to enable presentation of the observed phenomenon in graphical form. Standardisation is based on the z-score transformation of actual percentages, which standardises variables to the same scale, which is to 22-country mean, thereby producing new variables with a mean of 0 and a standard deviation of 1 . In some sense, this enables clearer graphical presentation of cross-country relationships than graphical presentation of original measures of variables would do. The same methodology has been applied also in figures 5 and 6.
} 
Primož Pevcin

Size and Development of the Third Sector:

An Insight Into Cross-Country Differences

\section{Figure 4: Welfare state and size of the non-profit sector ${ }^{20}$}

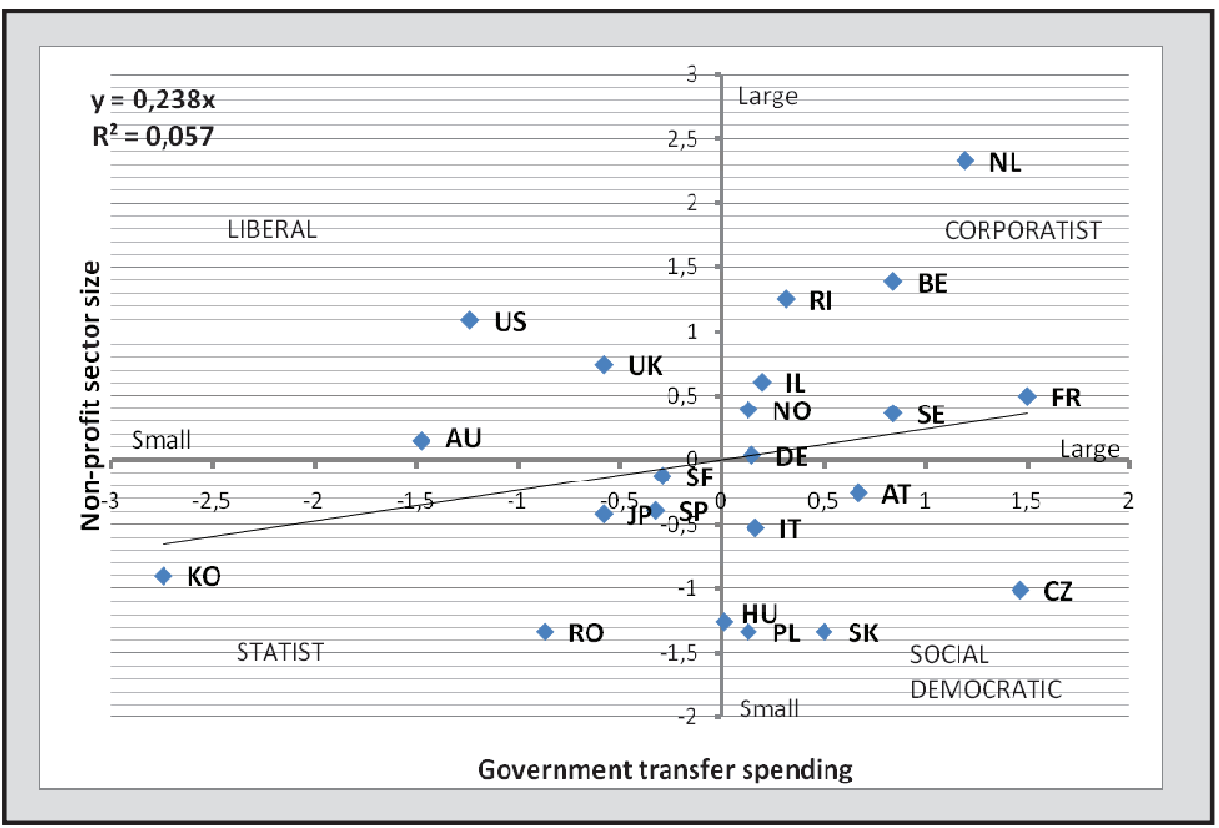

Source: Own calculations

As it can be observed from the figure 4, selected countries can be grouped and sorted in four distinctive regime types of non-profit sector activity. For instance, the majority of Western and Northern European countries, with the exception of the United Kingdom and Finland, belong to corporatist social regimes, where non-profit sector is in fact the extension of governmental welfare policy institutions. Specifically, the majority of Anglo-Saxon countries belong to liberal social regime, where non-profit sector basically acts as a substitution for smaller extent of governmental interventionism in welfare policies. Interestingly, the size of the non-profit sector is relatively small in all of the selected post-socialist countries, where predominantly social-democratic social regimes can be observed, where non-profit sector activity is "crowded-out « by governmental welfare policy interventionism. ${ }^{\mathbf{2 1}}$ Basically, two extreme cases

20 The sources of data are The John Hopkins Comparative Nonprofit Sector Project (2004) for the variable non-profit sector size and Economic Freedom of the World (2002) index for the variable government transfer spending size. Given the fact, that reference period for the first variable is 19952000; the data for the second variable refer to year 2000. The selection of countries is based on the availability of data, referring to their inclusion into the John Hopkins study.

21 Indeed, Jenei and Kuti (2008) argue that third sector organisations are quite vulnerable in postsocialist countries, as they do not have large independent foundations yet. They argue that third sector in those countries is often seen as the extension of government, as it is very important in the 
of statist social regimes can be observed, that is South Korea and Romania. In addition, the regression coefficient reveals that larger government transfer spending is associated the larger size of non-profit sector, although this relationship is relatively weak. ${ }^{\mathbf{2 2}}$ Nevertheless, this can somehow corroborate the hypothesis that both welfare state and non-profit activity are usually inclusive and not preclusive activities, meaning that they serve as an indication of socioeconomic development of society. Furthermore, this hypothesis has been validated in figure below, as relative strong and positive relationship exists between the level of GDP per capita and the size of non-profit sector. Basically, this supports the idea that the development and the size of non-profit sector are related to the level of economic development.

Figure 5: The level of country's economic development, measured with GDP per capita, and the extent of non-profit sector activity ${ }^{23}$

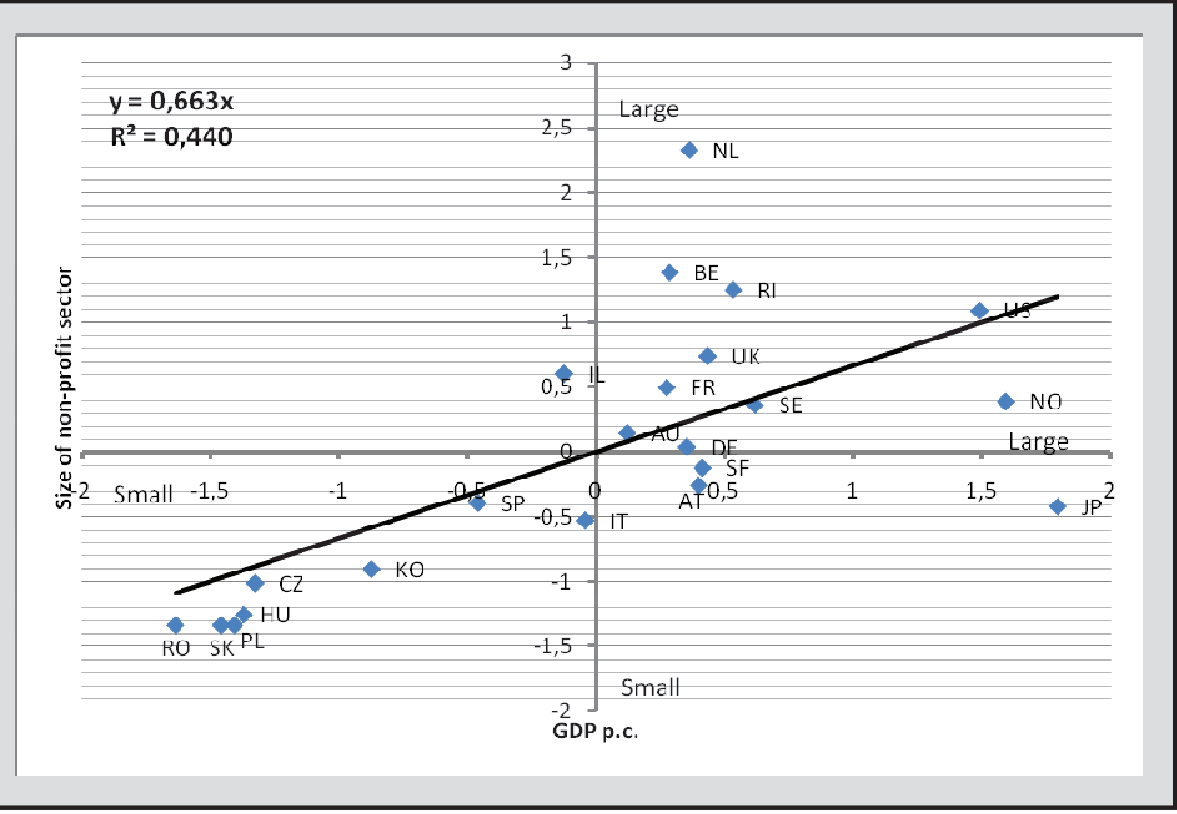

Source: Own calculations

provision of certain government services. Similarly, Nemec (2008) reveals for the case of postsocialist country of Slovakia, that both left-wing as well as right-wing governments tend not to take the third sector as a real partner in social process, in particular left-wing governments preferring "state production" of activities usually undertaken by third sector organisations.

22 These findings somehow even contradict the premises of above mentioned macrostructural approach.

23 The source of data for variable real GDP per capita is World Development Indicators (2001). Data are in U.S. dollars. Besides, it should be stressed that gross domestic product per capita is used as proxy for measuring the level of economic development, although the 
Primož Pevcin

Size and Development of the Third Sector:

An Insight Into Cross-Country Differences

Furthermore, the hypothesis on the relationship between the size of nonprofit sector and the level of ethno-cultural heterogeneity of society is tested below. A relatively viable proxy for determining the level of fragmentation of society is to determine the share of largest ethno-cultural group in total population, although the problems with clear definitions of such variable exist. ${ }^{\mathbf{2 4}}$ Nevertheless, this should be a relatively good, although quite subjective, indicator of homogeneity of society, so we should expect negative relationship between the ethno-cultural homogeneity of society and the extent of non-profit sector activity as there would be more demand for more universal type of collective goods. Still, as it can be observed from figure 6, the hypothesis could be validated, which is in line with Weisbrod's predictions, although the relationship is relatively weak in statistical terms.

\footnotetext{
later is much more broader concept, as it includes also social and technological progress of society not just progress in quantities of production. Namely, some non-mainstream economists claim that much of what had been taken as progress in modern societies is actually the consequence of a statistical fallacy, as conventional national income accounting systems do not take into account most of the real costs incurred to produce goods and services, simply because these costs do not pass through markets and, consequently, do not get prices. For instance, the costs of noise, air and water pollution are ignored because there is no easy way to measure them. If these costs of growth were taken into account, it would be seen that there had been much less of an increase in well-being than the conventional measures of national income implied (see Mishan, 1993). Following, gross domestic product does not, for instance, take into account environmentaly quality, social justice, leisure time, etc. However, given the fact that economists usually admit that it is difficult to measure social benefits and costs, and that, on aggregate, it is better to live in country with higher national income and domestic product levels, using this proxy seems quite plausible from economic perspective.

24 For instance, there is a problem with definition, which characteristics should be used when determining homogeneity of society, as population in certain country can be fragmented according to racial, cultural, ethnic or religious attributes, not excluding the combination of those attributes. Nevertheless, the approach taken here is to determine the fragmentation of society by exposing the attribute, which mostly affects fragmentation of society in each country. For instance, it is presumed that in United States the most important factor of fragmentation is race and in Belgium ethnic background. In contrast, in the case of Germany it is presumed that it is relatively homogenous society, although it is very divided in religious aspects - the presumption is that religion in this particular case does not play significant role in fragmentation process any more. The source of data for this variable is Encarta Encyclopaedia (2003).
} 
Size and Development of the Third Sector: An Insight Into Cross-Country Differences

Figure 6: Non-profit sector activity and ethno-cultural homogeneity of society $^{25}$

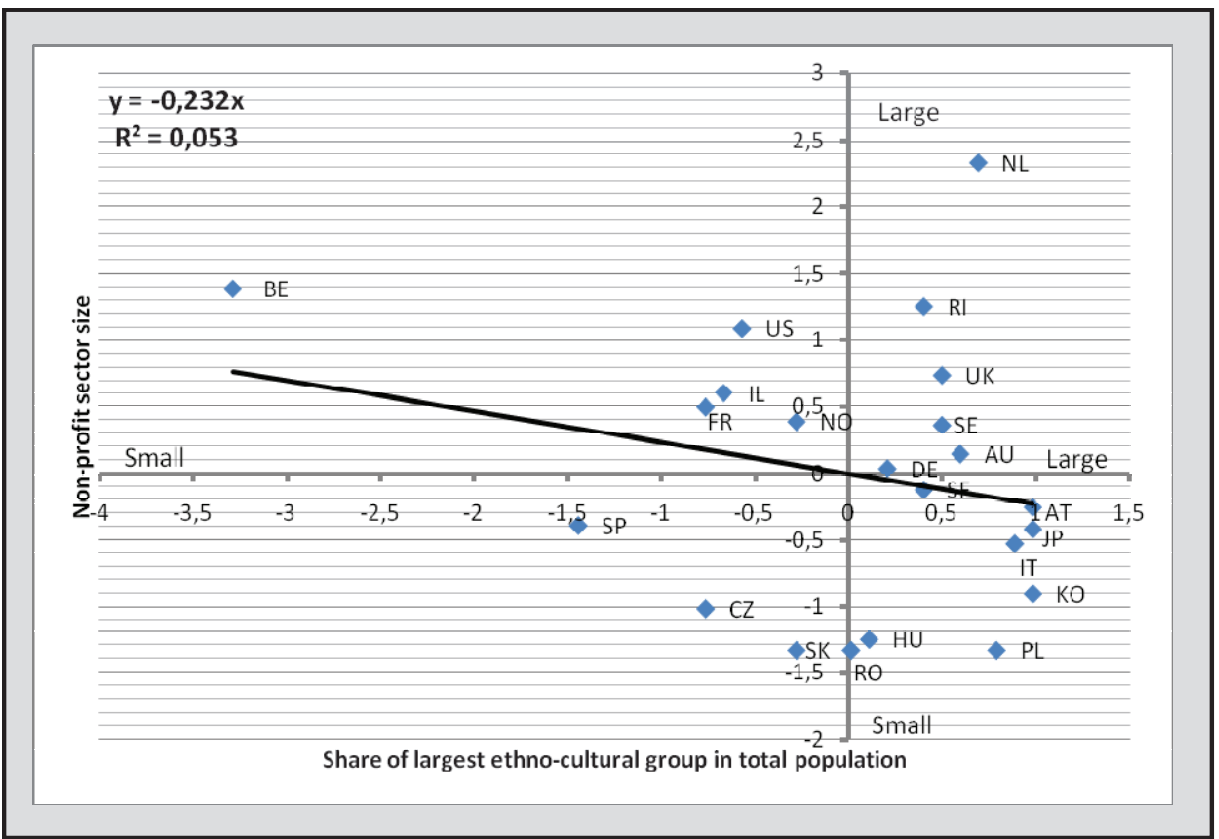

Source: Own calculations

\section{Concluding reflections}

The non-profit sector, organisations of which predominantly operate in the fields of education, health and social services, is a very important part of social system in modern societies. Yet, substantial differences exist in the development and importance of non-profit sector activities even among developed countries. In part, this can be attributed to the differences in the level of economic development, which is found to be an important determinant causing differences in the size of non-profit sector across countries, or to existing differences in

$\mathbf{2 5}$ Interestingly, it may seem from the graph, that the relationship could turn positive if Belgium is removed as an outlier. Nevertheless, if Belgium is dropped out from the sample, the relationship still remains negative, although it becomes weaker in statistical terms (beta coeficient is -0.007). The reason for this lies in the fact that removing one observation unit causes changes in the z-score values of all other variables included, since they become standardised to different scale. 
Primož Pevcin

Size and Development of the Third Sector:

An Insight Into Cross-Country Differences

social heterogeneity of society in each country. Moreover, those differences could also be addressed by changes and existing differences in socio-political environments of modern societies. Namely, the analysis presented in the paper reveals that selected countries can potentially be grouped in four different regime types of non-profit sector activities, each regime type denoting the relationship between the size of non-profit sector and the extent of governmental social activities in the form of matrix. Given the fact, that clear potential exist in grouping countries in four different regime types, those regime types being liberal, corporatist, statist and social democratic, the existence and validity of social origins theory of non-profit sector could be both theoretically and empirically validated and verified. Furthermore, it has been revealed that the size of non-profit sector is obviously positively related to the level of economic development and negatively related to the level of social homogeneity of society, both findings being in line with theoretical predictions.

Nonetheless, the issue of the cross-country variations in the size and development of non-profit sector should be further addressed, although problems exists in finding suitable and internationally comparable measures of non-profit sector activities, as only few data projects exist that are concerned with this issue. In particular, the research could be extended by performing multivariable regression analysis, including all potentially viable demand and supply side factors affecting differences in the size of the non-profit sector across countries, providing an insight into macro perspectives of non-profit sector development. Last but not least, the addressed issue of the commercialisation of non-profit organisations, which is changing thoroughly and dramatically the activities and operations of non-profit sector, has several pitfalls and limitations, which can ultimately lead to isomorphism of that sector with potentially severe adverse affects to society. Therefore, potential further research should also address the affect of commercialisation on the extent of non-profit sector activities, predominantly from the perspective of policy making in time.

Primož Pevcin, Ph.D. is Assistant Professor for Public Sector Economics at the Faculty of Administration, University of Ljubljana, Slovenia. He has earned his bachelor, master and doctoral degree from economics at the University of Ljubljana, Faculty of Economics. His research interest is predominantly focused on contemporary issues in economics of public and non-profit sector, as well as on economic analysis of law and political institutions. 


\section{Primož Pevcin \\ Size and Development of the Third Sector: An Insight Into Cross-Country Differences}

\section{References}

- (2001). World Development Indicators. Washington: World Bank.

- (2002). Economic Freedom of the World Annual Report. Vancouver: Fraser Institute.

- (2003). Encarta Encyclopaedia. Dublin: Microsoft.

- (2004). The John Hopkins Comparative Nonprofit Sector Project. Baltimore: John Hopkins Center for Civil Society Studies.

- Anderson, B., et.al. (2006). Budgeting in Norway. OECD Journal on Budgeting (6), 7-44.

- Anheier, H. (2000). Dimensions of the Third Sector: Comparative Perspectives on Structure and Change. Central Policy Unit Seminar: The Third Sector: Beyond Government and Market. July 2000. Retrieved 4. 2., 2010, from http://www.cpu.gov.hk/

- Annett, A. (2000). Social Fractionalization, Political Instability, and the Size of Government. Working Paper No. 82. Washington: International Monetary Fund.

- Brhlikova, P. (2004). The nonprofit sector in the Czech Republic. CERGE El Discussion Paper No. 128. Prague: Charles University.

- $\quad$ Euske, K.J. (2003). Public, private, not-for-profit: everybody is unique?. Measuring Business Excellence (7), 5-11.

- Ginnerup, R., et.al. (2007). Performance Budgeting in Denmark. OECD Journal on Budgeting (7), 67-90

- Giving in Europe. (n.d.). Retrieved 10. 10., 2009, from European Cross-Border Giving Database: http//www.givingineurope.org/

- Grønbjerg, K.A., \& Paarlberg, L. (2001). Community Variations in the Size and Scope of the Nonprofit Sector: Theory and Preliminary Findings. Nonprofit and Voluntary Sector Quarterly (30), 684-706.

- Jenei, G., \& Kuti, E. (2008). The Third Sector and Civil Society. In: Osborne, S.P. (ed.). The Third Sector in Europe: Prospects and Challenges. Abingdon: Routledge, 9-25.

- Macedo, I. M, \& Pinho, J.C. (2006). The relationship between resource dependence and market orientation: The specific case of non-profit organisations. European Journal of Marketing (40), 533-553

- Mishan, E. J. (1993). The Cost of Economic Growth. New York: Praeger Publishers.

- Nemec, J. (2008). The Third Sector and the Provision of Public Services in Slovakia. In: Osborne, S.P. (ed.). The Third Sector in Europe: Prospects and Challenges. Abingdon: Routledge, 118-133.

- NCVO (2008). Economic downturns and the voluntary and community sector: a short review of the evidence. NCVO Research. Retrieved 1. 6., 2009, from National Council for Voluntary Organisations: http://www.ncvo-vol.org.uk/

- Ott, J.S. (Ed.) (2001). The Nature of the Nonprofit Sector. Boulder: Westview Press. 
Primož Pevcin

Size and Development of the Third Sector:

An Insight Into Cross-Country Differences

- Robinson, M. (2007). Performance Budgeting: Linking Funding and Results. Palgrave Macmillan.

- Salamon, L.M. (1994). The Rise of the Nonprofit Sector. Foreign Affairs (73), 109-122.

- Salamon, L.M., \& Sokolowski, W. (2001). Volunteering in Cross-National Perspective: Evidence From 24 Countries. Working Paper No. 40. Baltimore: John Hopkins Center for Civil Society Studies.

- Salamon, L.M., et.al. (2007). Measuring Civil Society and Volunteering: Initial Findings from Implementation of the UN Handbook on Nonprofit Institutions. Working Paper No. 23. Baltimore: John Hopkins Center for Civil Society Studies.

- Shin, J., \& Milton, S. (2004). The effects of performance budgeting and funding programs on graduation rate in public four-year colleges and universities. Education Policy Analysis Archives (12), $27 \mathrm{p}$.

- Svitkova, K. (2004). The Evolution of the Third Sector in Slovakia. CERGE El Discussion Paper No. 122. Prague: Charles University.

- Weisbrod, B.A. (Ed.) (1998). To Profit or Not to Profit: The Commercial Transformation of the Nonprofit Sector. Cambridge: Cambridge University Press. 
POVZETEK

\section{OBSEG IN RAZVITOST TRETJEGA SEKTORJA: ANALIZA RAZLIK MED DRŽAVAMI}

Tretji oziroma nepridobitni sektor vključuje različne organizacije, katerih namen je zadovoljevanje določenih potreb prebivalstva. Te organizacije delujejo predvsem na področju sociale, zdravstva, izobraževanja in raziskovalne dejavnosti, umetnosti ter kulture, športa itd. Razvitost nepridobitnega sektorja je povezana $z$ ekonomskih stanjem $v$ državi, z obsegom izvajanja določenih javnih politik, s spremembami $v$ številu prebivalstva, $s$ spremembami $v$ strukturi preferenc posameznikov itd. Velika posebnost tega sektorja je $v$ tem, da so pomemben delež virov za njegovo delovanje tudi prostovoljne donacije, ki jih organizacijam $v$ teh sektorju namenjajo predvsem posamezniki in organizacije pridobitnega sektorja. Omeniti velja, da je trenutna gospodarska kriza bolj ali manj paralizirala precejšen del pridobitnega sektorja, pri čemer se politike vladnega sektorja $v$ večini držav osredotočajo na odpravljanje posledic takšnega stanja. Politike dejansko povečujejo aktivno ekonomsko vlogo države, zato se odnos med vladnim in pridobitnim sektorjem vse bolj spreminja iz konstitucionalizma $\checkmark$ paternalizem. $V$ tem kontekstu se povečuje pomen tudi nepridobitnega sektorja. Namreč, izkušnje iz preteklih ekonomskih kriz kažejo, da se pomen nepridobitnega sektorja povečuje ravno $v$ kriznih razmerah, saj je za ta sektor značilno, da prihaja $v$ takšnih razmerah do povečevanja povpraševanja po njegovih produktih in storitvah (npr. dobrodelne organizacije, izobraževalne organizacije itd.), hkrati pa je za ta sektor značilna tudi relativno manjša občutljivost na gospodarska gibanja, kar velja tudi za finančne vire organizacij $v$ tem sektorju (NCVO, 2008). Dva glavna razloga za povečevanje pomena nepridobitnega sektorja $v$ kriznih razmerah naj bi bila, da so po eni strani viri organizacij tega sektorja pogosto precej razpršeni, po drugi strani pa je sektor neke vrste "bazen « družbe za mobilizacijo virov v kriznih razmerah. Namreč, družbene mreže, ki sestavljajo nepridobitni sektor, omogočajo izjemno hitro in učinkovito mobilizacijo človeških virov, povezanih $v$ ta sektor, za uresničitev nekaterih ciljev družbe, ne da bi bilo treba vzpostavljati državno prisilo ali zagotavljati ekonomske spodbude. Delovanje nepridobitnega sektorja namreč po Ottu (2001) temelji na obstoju t. i. ekonomije dotacij, ki vključuje prostovoljno donacijo časa, denarja itd., kar v nasprotju z državno prisilo in tržno ekonomijo omogoča delovanje nepridobitnega sektorja dejansko na skoraj 
Primož Pevcin

Size and Development of the Third Sector:

An Insight Into Cross-Country Differences

vseh področjih družbenega življenja, pogostokrat precej neodvisno od aktualnih političnoekonomskih razmer.

Omeniti velja, da obstajajo precejšnje razlike med državami v velikosti in relativnem družbenoekonomskem pomenu nepridobitnega sektorja. Pri tem se $v$ teoriji pojavljajo različne teze, ki pojasnjujejo potencialne razloge za razlike $v$ velikosti nepridobitnega sektorja, pri čemer lahko te teze razvrstimo $v$ dve skupini. Prva skupina tez, ki je usmerjena na t. i. povpraševalno stran, se osredotoča na vlogo tretjega sektorja pri zagotavljanju produktov in storitev, ki jih nista $v$ ustreznem obsegu zagotovila pridobitni in vladni sektor. V nasprotju s tem se druga skupina tez, ki je usmerjena na t. i. ponudbeno stran, osredotoča predvsem na povezave med velikostjo nepridobitnega sektorja in obsegom sredstev, ki so na razpolago sektorju, kar implicira, da naj bi bil pomemben dejavnik razvitosti nepridobitnega sektorja ravno ekonomska razvitost družbe. Pri tem velja omeniti, da empirične analize $v$ praksi potrjujejo predvsem veljavnost $t$. i. ponudbenih tez, predvsem $v$ smislu, da na razvitost nepridobitnega sektorja vplivajo zlasti ustrezne in stimulativne družbenoekonomske razmere $\checkmark$ družbi. Razlike $v$ velikosti in razvitosti nepridobitnega sektorja med državami po drugi strani implicirajo obstoj različnih družbenih režimov, ki označujejo razmerja med vladnim in nepridobitnim sektorjem pri izvajanju določenih družbenih funkcij in zagotavljanju določenih produktov in storitev, ki zadovoljujejo potrebe prebivalstva. $S$ tem $v$ zvezi je glavni namen prispevka teoretično in empirično analizirati potencialne dejavnike, ki vplivajo na razlike $v$ velikosti in razvitosti nepridobitnega sektorja na izbranem vzorcu 22 demokratičnih držav, posredno pa praktično preveriti obstoj različnih družbenih režimov, ki opisujejo razmerja med vladnim in nepridobitnim sektorjem. $V$ bistvu prispevek nadgrajuje raziskave Salamona in Sokolowskega (2001) s preverjanjem veljavnosti obstoja različnih družbenih režimov $v$ praksi, hkrati pa empirično ugotavlja povezave med gospodarsko razvitostju družbe, njeno etnokulturno raznovrstnostjo in velikostjo nepridobitnega sektorja. Namen prispevka je praktično preveriti veljavnost ponudbenih in povpraševalnih tez o razvitosti nepridobitnega sektorja. Rezultati empirične analize potrjujejo obstoj različnih družbenih režimov $v$ praksi, kar pomeni, da lahko posamezne države razvrstimo $v$ štiri različne družbene režime, ki opisujejo razmerja med vladnim in nepridobitnim sektorjem pri zagotavljanju določenih produktov in storitev prebivalstvu. Ti režimi so statični, socialno demokratski, liberalni in korporativistični. Za prva dva režima je značilen relativno majhen družbenoekonomski pomen nepridobitnega sektorja. $\checkmark$ statičnem režimu naj bi bile glavni razlog za to omejitve, ki jih $v$ delovanje 
nepridobitnega sektorja vpeljuje politični sistem, v socialno demokratskem režimu pa obsežno vladno zagotavljanje dobrin in storitev prebivalstvu, ki zmanjšuje potrebo po delovanju nepridobitnih organizacij na tem področju. Po drugi strani je za liberalni in korporativistični režim značilno, da je relativni družbenoekonomski pomen nepridobitnega sektorja velik, pri čemer naj bi bil v liberalnem režimu glavni razlog za to izostanek državnega intervencionizma na področju družbenih dejavnosti, medtem ko je pri korporativističnem režimu vloga nepridobitnega sektorja poudarjena predvsem $v$ obliki podpornega mehanizma vladnemu sektorju pri izvajanju določenih politik in zagotavljanju določenih produktov in storitev. Rezultati empirične analize kažejo, da je $v$ grobem liberalni režim značilen predvsem za anglosaksonske države, korporativistični predvsem za zahodnoevropske države, socialno demokratski režim za srednje in južnoevropske države, medtem ko je statitični režim značilen predvsem za novo industrializirane oziroma relativno manj razvite države. Empirična analiza je tudi pokazala, da sta velikost in razvitost nepridobitnega sektorja pozitivno povezana z ekonomsko razvitostjo družbe in negativno povezana $z$ njeno etnokulturno homogenostjo, kar je skladno $s$ teoretičnimi pričakovanji, da naj bi bil pomemben dejavnik razvitosti nepridobitnega sektorja ravno razvitost družbe same, po drugi strani pa naj bi na povpraševalni strani na potrebo po obstoju nepridobitnega sektorja vplivale ravno razlike $v$ preferencah posameznikov, ki so pozitivno povezane $s$ heterogenostjo družbe. Namreč, $v$ tem primeru nepridobitni sektor služi kot orodje zadovoljevanja specifičnih potreb prebivalstva, ki jih vladni sektor s pretežno univerzalnimi produkti in storitvami ne more.

Nenazadnje, prispevek poleg tega obravnava nekatere mogoče pasti $v$ razvoju nepridobitnega sektorja $v$ prihodnosti, ki se nanašajo predvsem na čedalje izrazitejše težnje po komercializaciji delovanja nepridobitnih organizacij in njihovi čedalje večji ekonomski učinkovitosti. Podatki kažejo, da so $t$. i. komercialni viri postali $v$ povprečju že najpomembnejši viri, ki omogočajo delovanje nepridobitnih organizacij. Poudariti velja, da je na zahteve po komercializaciji delovanja imela še posebej velik vpliv $\vee$ zadnjih desetletjih močno uveljavljena ideologija novega javnega menedžmenta, ki je tudi od teh institucij zahtevala bolj tržno ravnanje in usmeritev pri poslovanju. Te zahteve se po navadi izražajo bolj posredno, predvsem $z$ različnimi spremembami $v$ načinu financiranja, ki posledično zahtevajo večje pridobivanje sredstev na trgu, če te organizacije sploh želijo normalno delovati. Čeprav je komercializacija delovanja dejansko v nasprotju z namenom delovanja nepridobitnih organizacij, pa je danes $v$ praksi postala za precejšen 
Primož Pevcin

Size and Development of the Third Sector:

An Insight Into Cross-Country Differences

delež teh organizacij že prevladujoči način delovanja. $V$ splošnem velja, da se je nepridobitni sektor relativno uspešno spoprijel z nujo po večji komercializaciji delovanja, velja pa tudi omeniti, da to nepridobitnemu sektorju prinaša tudi določene probleme. Takšen primer je na primer tesno sodelovanje $s$ pridobitnim sektorjem, ki pogosto prinaša določene omejitve oziroma "pogoje" v delovanju nepridobitnega sektorja, kar vpliva na njegovo že prej omenjeno neodvisnost oziroma avtonomijo, nenazadnje pa lahko pripelje tudi do pojava organizacijskega izomorfizma. 